\title{
INFILTRATION LOSSES CALCULATED FOR THE FLASH FLOOD IN THE UPPER CATCHMENT OF GERU RIVER, GALAŢI COUNTY, ROMANIA
}

\author{
Isabela Balan ${ }^{1}$, Loredana Crenganiș ${ }^{2}$, Flaviana Corduneanu $^{3}$, \\ Claudiu Pricop ${ }^{1}$, Loredana Andreea Popoiu ${ }^{1}$
}

Keys words: MIKE software by Danish Institute of Hydraulics, flash flood, UHM, infiltration, radar precipitation

\begin{abstract}
MIKE software created by Danish Institute of Hydraulics can be used to perform mathematical modelling of rainfall-runoff process on the hillslopes, resulting in a runoff hydrograph in the closing section of a catchment. The software includes a unitary hydrograph method - UHM in the hydrological module Rainfall Runoff. Excess rainfall is routed to the river and transited through unit hydrograph method. The model divides the flood generating precipitation in excess rainfall (net rainfall) and losses (infiltration).

This paper analyzes data from the flash flood that occurred between the $11^{\text {th }}$ and $13^{\text {th }}$ of September 2013 in the upper catchment of the river Geru. The catchment chosen for study, is controlled by the hydrometric station located in the village Cudalbi. Simulations of this flash flood were performed with MIKE by DHI -UHM software, alternatively using as input data the precipitations recorded by AHSS (Automated Hydrological Sensor Station) Cudalbi and radar precipitations generated by ROFFG (Romanian Flash Flood Guidance) software system in ArcGIS module for determining the areas affected by flash floods. The Unitary Hydrograph Method $U H M$ from the hydrological module Rainfall - Runoff calculates excess rainfall and determines infiltration losses by four methods. For each set of input data, the four methods for calculating infiltration losses were subsequently used.

The comparison between the results highlights that the amplitude and phase errors for the maximum discharge are smaller when the model uses for simulation radar

\footnotetext{
${ }^{1}$ Water Basinal Administration Prut-Bârlad, isabela.balan@yahoo.co.uk

${ }^{2}$ Lecturer PhD., "Gheorghe Asachi" Technical University of Iasi, Romania

${ }^{3}$ University of Agricultural Sciences and Veterinary Medicine, Iasi, Romania
} 
precipitations as input data, and calculates infiltration losses with the Proportional Loss method. This method reproduces with a better accuracy the peaks of the discharge hydrograph. The model can be used in the future to forecast a discharge hydrograph based on estimated radar precipitations in the catchment

\section{Introduction}

A storm event causing a flash flood can be simulated with the Unitary Hydrograph Method. The Unit hydrograph function is the response of the catchment to a $1 \mathrm{~mm}$ net rainfall, uniformly distributed on the surface of the catchment and having the duration $\Delta t$; it is defined by the ordinates:

$$
\mathrm{U} \cdot \mathrm{H} .=\left\{\mathrm{u}_{\mathrm{i}}=\mathrm{u}(\mathrm{i}, \Delta \mathrm{t})\right\} ; \mathrm{i}=1,2, \ldots \ldots, \mathrm{n}_{\mathrm{u}}
$$

where $u_{i}$ is the ordinate of the unit hydrograph at the moment of time $i ; \mathrm{n}_{\mathrm{u}}$ is the number of ordinates taken into account, so that:

$$
\sum_{i=1}^{n_{u}} u_{i} \approx \frac{1}{T}
$$

where $T$ is the number of hours of time step $\Delta t$.

Usually a unit hydrograph is derived from historical rainfall and runoff data. The volume of water produced by the storm (total area under the hydrograph curve) divided by the area of the watershed equals depth of excess precipitation. The ordinates of the storm hydrograph are divided by this depth to obtain the unit hydrograph. If no historical rainfall and runoff data is available the hydrograph can't be obtained in the way presented above. The other methods for the determination of the unit hydrograph that appeared are called synthetic unit hydrographs. The two widely known methods for determination of the unit hydrographs are the Snyder method (1938) and the USDA SCS (United States Department of Agriculture Soil Conservation Service) method.

The USDA SCS method is a method used to create an adimensional hydrograph with ordinate values expressed in a ratio Q/Qp (flow/peak flow) and containing the values of the ratio $t / t p$ (time/time to peak) on the abscissa. The dimensionless unit hydrograph can be used later to determine a watershed specific unit hydrograph knowing some characteristics of the watershed.

The data needed to apply the method are: the area of the catchment $A$, the time of concentration $T_{c}$ and the duration of the unit excess rainfall $D$. The concentration time can be calculated using different formulas like the Kirpich/Ramser formula. (Domnița M., 2012) 
The SCS curve number method is a simple method used on large scale for determination of the approximate runoff value corresponding to a certain rainfall quantity in a certain area. Although the method is designed for a single storm, it can be scaled to calculate the annual values for runoff in an area.

The SCS-CN method was developed in 1954 and it is documented in Section 4 of the National Engineering Handbook (NEH) published by Soil Conservation Service (now called the Natural Resources Conservation Service), U.S. Department of Agriculture in 1956.

MIKE by DHI software can be used to perform mathematical modelling of rainfall-runoff process on the hillslopes, resulting in a runoff hydrograph in the closing section of a catchment. The software includes a unitary hydrograph method - UHM in the hydrological module Rainfall - Runoff. Mathematical modelling of rainfall-runoff process on the hillslopes, resulting in a runoff hydrograph in the closing section of a catchment can be achieved using MIKE by DHI software, which includes in the hydrological module Rainfall - Runoff, a unit hydrograph model (UHM).

Excess rainfall is routed to the river and transited through unit hydrograph method. The model divides the flood generating precipitation in excess rainfall (net rainfall) and losses (infiltration).

The $U H M$ calculates excess rainfall and determines infiltration losses by four methods:

- SCS method using Curve Number parameter to characterize the analyzed catchment from the perspective of existing soil type and land use patterns.

- constant loss method that sets an initial fixed value and a constant value during rainfall

- rational method that describes infiltration as a proportional loss.

- SCS method generalized using Curve Number parameter and initial infiltration

The runoff curve number (also called a curve number or simply $C N$ ) is an empirical parameter corresponding to different soil-vegetation-land use combinations. The SCS Curve number method only forecasts the quantity of runoff formed in any point of the catchment but does not model the flow routing or the distribution of runoff through time. Because of this reason the requirements of the method are quite low, only the rainfall depth and an empirical parameter named the Curve Number are mandatory. The Curve Number $(\mathrm{CN})$ value can be obtained from the hydrologic soil group, landuse and moisture conditions of the soil, the last two values being more important. (Domnița M., 2012)

The SCS-CN method is based on the water balance equation and two fundamental hypotheses (Mishra and Singh, 2003).

The water balance equation states that: 


$$
P=I_{a}+F+Q
$$

The first hypothesis states that the ratio of the actual amount of direct runoff to the maximum potential runoff is equal to the ratio of the amount of actual infiltration to the amount of the potential maximum retention:

$$
\frac{Q}{P-I_{a}}=\frac{F}{S}
$$

The second hypothesis states that the amount of initial abstraction is some fraction of the potential maximum retention.

$$
I_{a}=\lambda * S
$$

where: $P=$ total precipitation $(\mathrm{mm})$;

$I_{a}=$ initial abstraction (mm);

$F=$ cumulative infiltration excluding $I_{a}(\mathrm{~mm})$;

$Q=$ direct runoff $(\mathrm{mm})$

$S=$ potential maximum retention or infiltration;

The values of the $C N$ can be found in chapter 9 of the NEH - National Engineering Handbook for different land uses and soil groups (USDA, 1986). These values were obtained from data on floods, annual rainfall and runoff values taken from scientific literature for a large variety of catchments, usually small catchments under $1 \mathrm{~km}^{2}$ (USDA-SCS, 1985).

The SCS - NRCS for estimating the discharge evaluates the effects of the catchment area through landuse and the type of treatment applied to agricultural cultures.

A source of variability is also the antecedent moisture condition (Antecedent Moisture Condition - AMC). The SCS methodology represents this parameter based on the cumulated precipitation over the previous five days in the following way (McCuen, 1982):

1. AMC I represents dry soil, with cumulated precipitation $<12.7 \mathrm{~mm}$ in the dormant season and $<35.6 \mathrm{~mm}$ in the growing season.

2. AMC II represents medium soil moisture, with cumulated precipitation of $12.7-28 \mathrm{~mm}$ in the dormant season and $35.6-53.4 \mathrm{~mm}$ in the growing season.

3. AMC III represents moist or saturated soil, with cumulated precipitation $>$ $28 \mathrm{~mm}$ in the dormant season and $>53.4 \mathrm{~mm}$ in the growing season. 
These values of AMC correspond, respectively, to 90,10 , and $50 \%$ cumulative probability of exceedance of runoff depth for a given rainfall (Hjelmfelt et al., 1982).

The Curve Numbers are calculated for $A M C I I$ and then adjusted by addition to simulate $A M C I I I$ or subtraction to simulate $A M C I$. (Domnița M., 2012)

\section{Material and method}

According to the principle of superposition UHM determines a discharge hydrograph for each time step and excess rainfall, according to the method of infiltration losses and then adds the runoff generated in the precedent time step.

Figure 1 presents MIKE 11 by DHI - UHM menu for selecting the parameters.

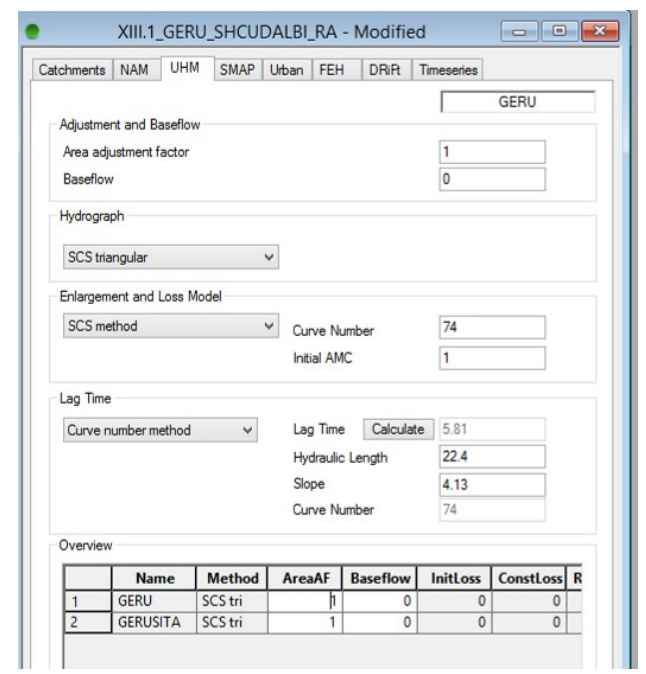

Fig. 1. MIKE 11 by DHI - UHM menu

The model is applied to the upper basin of the river Geru located in Galaţi county. The upper catchment chosen for study, has an area of $99.52 \mathrm{~km}^{2}$, and is controlled by the hydrometric station located in the village Cudalbi, located at $22.53 \mathrm{~km}$ downstream (figure 2). The daily transmitted data from the classic hydrometric station with vertical hydrometric are doubled since August 2013 by hourly precipitation data from an AHSS (Automated Hydrological Sensor Station).

Between $11^{\text {th }}$ and $13^{\text {th }}$ of September in the upper catchment of river Geru large quantities of precipitation occurred. The storm generated a flow hydrograph with three peaks, with the following maximum discharges: $118.00 \mathrm{~m}^{3} / \mathrm{s}$ recorded on $12 / 09 / 201323^{00}$, then $75.30 \mathrm{~m}^{3} / \mathrm{s}$ recorded on $13 / 09 / 201302^{20}$, respectively 10.30 $\mathrm{m}^{3} / \mathrm{s}$ recorded on $13 / 09 / 201310^{00}$. The flow hydrograph was extracted from the 
rating curve calculated by the Hydrology Department of the Basinal Water Administration Prut - Bârlad for the cross section of the river Geru at Cudalbi hydrometric station.

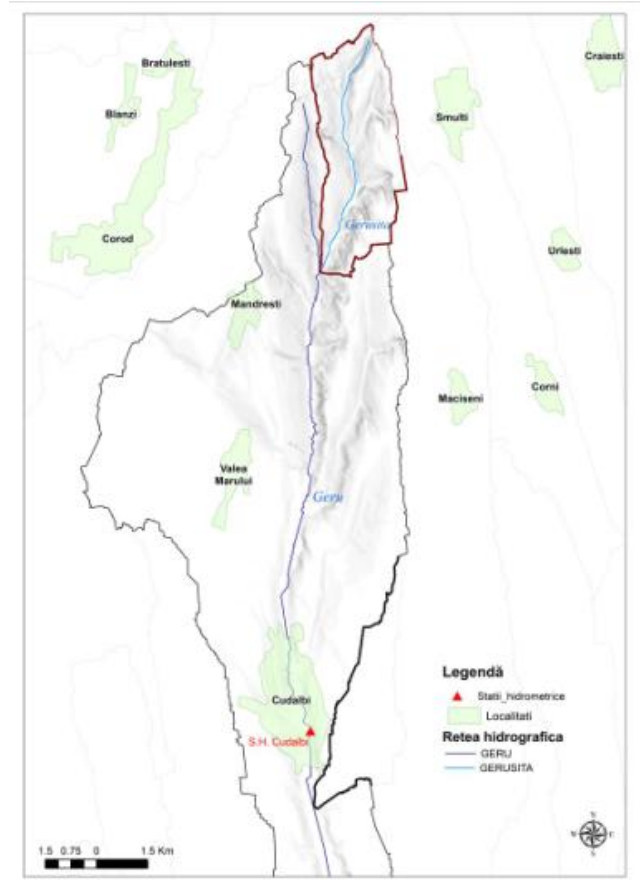

Fig. 2. Map of the upper catchment of river Geru

It appears that the flood that occurred between $11^{\text {th }}$ and $13^{\text {th }}$ of September 2013 had a maximum discharge of $118.00 \mathrm{~m}^{3} / \mathrm{s}$ that is very close to the peak of the flood with a $2 \%$ probability of exceedance, which is $120.00 \mathrm{~m}^{3} / \mathrm{s}$, established by the National Institute of Hydrology and Water Management, for the analyzed section.

To simulate the flood that occurred between $11^{\text {th }}$ and $13^{\text {th }}$ of September 2013 we used a hydrological model that included the river Geru and its tributary, the river Geruşiţa and used the Unitary Hydrograph Method from the Rainfall - Runoff Module, in order to obtain the runoff hydrograph recorded at the hydrometric station.

The evolution of the runoff was described with the triangular hydrograph SCS method (Soil Conservation Service of USDA), which established that the moment of occurrence of the maximum flow (peak hydrograph) is considered to be at half the duration of the rain, plus the duration between the nucleus of the rain and the peak of the runoff; 
Mostly clay soil and clay loam, with low infiltration are spread in the river Geru catchment. The soils are classified in the group $C$ of hydrologic soils. For the analyzed catchment the $C N$ (Curve Number) parameter was calculated by the weighted method established in TR - 55 (Technical Release - 55) by the United States Department of Agriculture. The method is applicable to small basins and $C N$ parameter is calculated as a weighted average based on land use and $C N$ intermediate surface corresponding to each surface.

For a catchment that is composed of different hydrologic soil groups and different land use, the Curve Number parameter can be calculated with the equation (5) for average humidity conditions $A M C I I$ :

$$
C N_{\text {weighted }}=\frac{\sum A_{i} \cdot C N_{i}}{\sum A_{i}}
$$

where: $\boldsymbol{C N}_{\text {weighted }}$ is a weighted $C N$ parameter

$\boldsymbol{i}=$ an index of the subdivions with the same hydrologic soil type and land use

$\boldsymbol{C N}_{\boldsymbol{i}}=\mathrm{CN}$ corresponding to the subdivision , i"

$A_{i}=$ draining surface of the subdivision ,i” (USACE, 2000).

$C N$ parameter obtained is a weighted value that represents all the possible combinations of hydrologic soil groups and land use in a catchment. (Györi et al., 2013).

Before the hydrologic event that occurred between the $11^{\text {th }}-14^{\text {th }}$ of September 2013, the cumulative precipitations in five precedent days were less than $35.6 \mathrm{~mm}$, which is the limit set by McCuen, 1982 for the spring - summer period, that characterizes a dry soil, close to a wilting point. For the initial moisture condition we used $\mathrm{AMC}=1$ for dry soil. The parameter Curve Number calculated for $A M C I I$ was adjusted by substraction to obtain the corresponding parameter for $A M C I$. For river Geru catchment the value $\boldsymbol{C N}=\mathbf{7 4}$ is obtained.

\section{Results and discusion}

Simulations of this flash flood were performed with MIKE by DHI -UHM software, alternatively using as input data the precipitations recorded by AHSS Cudalbi and radar precipitations generated by ROFFG (Romanian Flash Flood Guidance) software system in ArcGIS module for determining the areas affected by flash floods. The Unitary Hydrograph Method - UHM from the hydrological module Rainfall - Runoff calculates excess rainfall and determines infiltration losses by four methods. For each set of input data, the four methods for calculating infiltration losses were subsequently used. 


\subsection{Precipitations recorded by AHSS Cudalbi as input data}

The precipitations recorded by AHSS Cudalbi with a 10 minute time step are presented in figure 3.

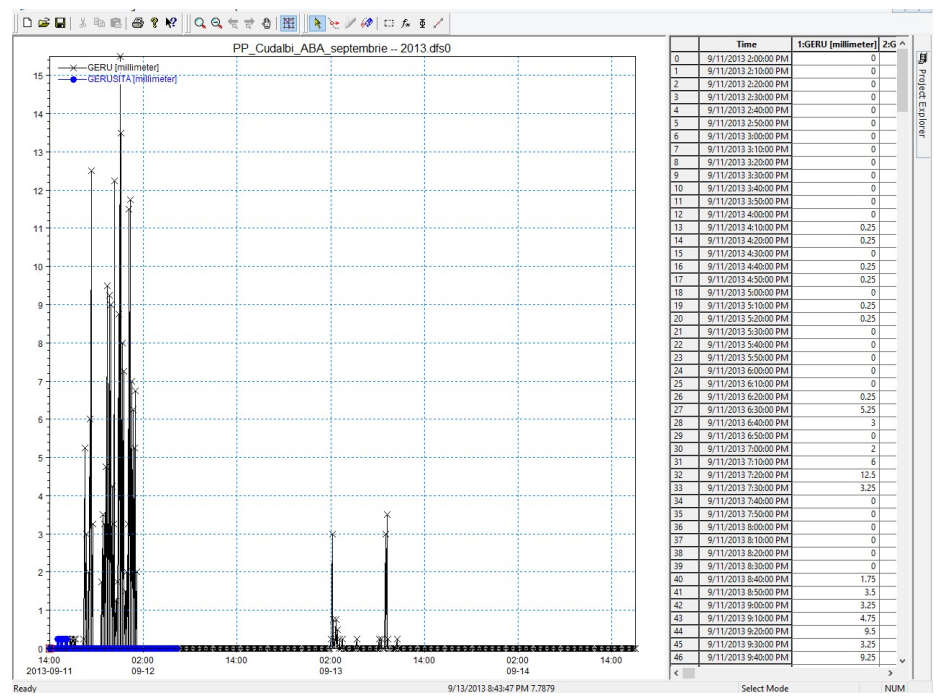

Fig. 3 - Precipitations recorded at AHSS Cudalbi during the $11^{\text {th }}-14^{\text {th }}$ of September 2013

After performing several trial-and-error simulations we concluded that the value $\mathbf{0 . 7 1}$ for the area adjustment factor parameter represents the real proportion between the rain intensity in the catchment and the precipitations recorded at AHSS Cudalbi.

\section{SCS Method for infiltrations}

When we used the value $\mathbf{0 . 7 1}$ for the area adjustment factor parameter, in the parameters menu, the simulation led to a peak discharge of $120.10 \mathrm{~m}^{3} / \mathrm{s}\left(12^{\text {th }}\right.$ of September $2013,06^{60}$ ), with a $1.8 \%$ increase compared to the maximum recorded discharge of $118.00 \mathrm{~m}^{3} / \mathrm{s}\left(11^{\text {th }}\right.$ of September $\left.2013,23^{00}\right)$, and a delay of 7 hours.

The comparison of the measured and simulated flow hydrograph highlights that is possible that some precipitations fell in the upstream side of the analyzed catchment and were not captured by the automated station located downstream. The missing precipitations from the recordings may have in fact contributed to the measured surface runoff that showed three peaks. The simulated hydrograph did not catch the three discharge peaks.

\section{CONSTANT LOSS Method for infiltrations}

The CONSTANT LOSS Method describes the infiltration through Initial Loss parameter (initial infiltration, at the beginning of the rain) and Constant Infiltration parameter (constant infiltration throughout the rain). 
We calculated the maximum retention potential, which expresses the retention capacity of the soil, $S$.

$$
S=\frac{1000}{C N}-10=\frac{1000}{73}-10=3.69 \text { inch }=93.94 \mathrm{~mm}
$$

Initial infiltration $I_{a}$ depend directly of the maximum retention, in the equation:

$\mathrm{I}_{\mathrm{a}}=0.2 \cdot \mathrm{S}=3.69 \cdot 93.94=18.8 \mathrm{~mm}$

Several simulations were performed using the precipitations recorded at AHSS Cudalbi, gradually increasing the constant infiltration throughout the rain, starting with the value Constant loss $=5 \mathrm{~mm} / \mathrm{h}$, till we established a value for the parameter, which led to a discharge hydrograph similar to the measured hydrograph, by phase and amplitude. We reached the conclusion that the value 26 $\boldsymbol{m} \boldsymbol{m}$ for the parameter Constant Loss led to a peak discharge of $118.85 \mathrm{~m}^{3} / \mathrm{s}$ with a $0.7 \%$ increase and a 7 hours delay compared to the maximum recorded discharge.

PROPORTIONAL LOSS Method for infiltrations

Several simulations were performed gradually decreasing the value for the parameter Runoff coefficient, starting with the value 0.5 , till we established a value for the parameter which led to a discharge hydrograph similar to the measured hydrograph, by phase and amplitude. We reached the conclusion that the value $0.27 \mathrm{~mm}$ for the parameter Runoff coefficient led to a peak discharge of $117.71 \mathrm{~m}^{3} / \mathrm{s}$ with a $0.2 \%$ decrease and a 6 hours delay compared to the maximum recorded discharge.

SCS GENERALISED Method for infiltrations

The SCS generalised method calculates the infiltration losses and water retention in the depressions uses $\boldsymbol{C N}$ (Curve Number) parameter and Initial abstraction depth parameter.

Several simulations were performed using different values for the Initial abstraction depth parameter, till we established a value for the parameter, which led to a discharge hydrograph similar to the measured hydrograph, by phase and amplitude. We reached the conclusion that the value $73 \mathbf{m m}$ for the parameter Initial abstraction depth led to a peak discharge of $118.09 \mathrm{~m}^{3} / \mathrm{s}$ with a $0.08 \%$ increase and a 7 hours delay compared to the maximum recorded discharge.

\subsection{Precipitations radar as input data}

RADAR technology represents a fixed installations that uses electromagnetic waves and their reflection from different objects, to determine their relative position towards the antenna. The meteorological radar can be used to determine location, movement and type of the precipitations and to estimate the future changes of position and intensity. The modern Doppler radar can not only detect the intensity of the rain, but also can detect the movement of the precipitations. The 
information provided by the radar is analyzed in order to identify the structure of the rainfall and the possibility of weather changes. The weather stations have their own data base with climate variables, that are stored in specific tables constantly update by the National Administration of Meteorology.

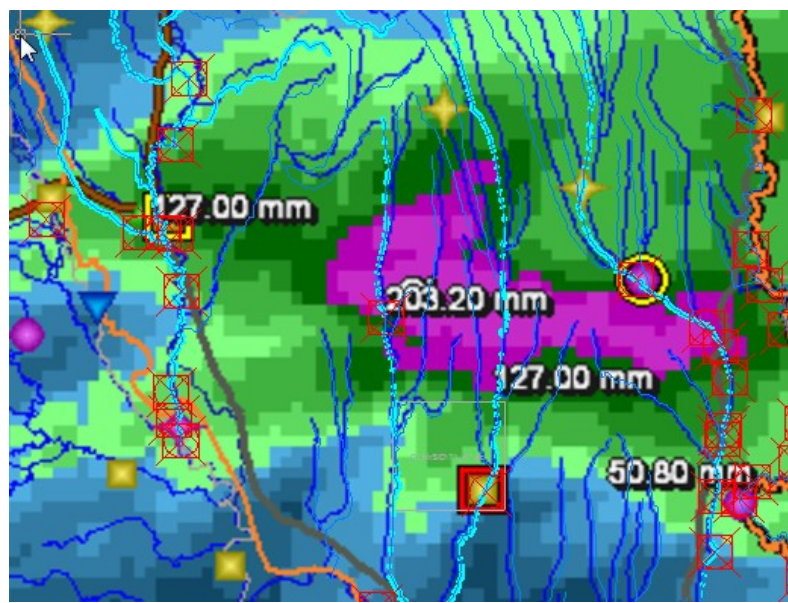

Fig. 4. Spatial distribution of the precipitations

The values of the radar precipitations that occurred between the $11^{\text {th }}$ and $13^{\text {th }}$ of September 2013 were generated by the ROFFG (Romanian Flash Flood Guidance) software system in ArcGIS environment used to determine the areas affected by flash floods in small catchments throughout Romania.

From data processed by the ROFFG system, we used the product Merged Map - medium precipitation accumulated in an hour, based on the spatial and temporal estimations of the precipitations, corrected and/or based on the precipitations recorded on the ground, by the automated station (figure 4).

The values of the radar precipitations with an hourly frequency are presented in figure 5 .

SCS Method for infiltrations

For the simulations performed using the radar precipitations we used area adjustment factor $=\mathbf{1}$, because we considered that the data input accurately characterizes the catchment, and the file show a temporal distribution close to reality.

The simulations led to a maximum peak of $128.25 \mathrm{~m}^{3} / \mathrm{s}$ (the $12^{\text {th }}$ of September $2013,05^{00}$ ), with a $8.7 \%$ increase and 6 hours delay, compared to the maximum recorded discharge. 
The second peak of $89.82 \mathrm{~m} 3 / \mathrm{s}$ (the 13 th of September 2013, 0716) has a $19 \%$ increase and a 5 hours delay, compared to the second recorded peak of $75.30 \mathrm{~m} 3 / \mathrm{s}$ (the 13 th of September 2013, 0220).

The third peak of $7.47 \mathrm{~m} 3 / \mathrm{s}$ (the 14 th of September 2013, 1630) has a $27 \%$ increase and a 30 hours delay, compared to the third recorded peak of $10.30 \mathrm{~m} 3 / \mathrm{s}$ (the $13 \mathrm{th}$ of September 2013, 1020).

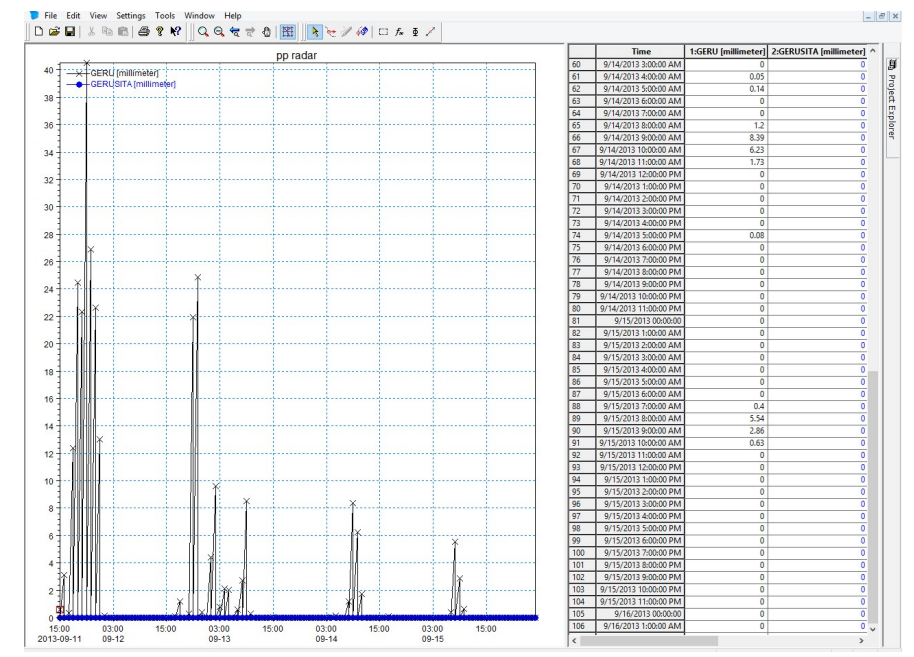

Fig. 5. Radar precipitations produced between the $11^{\text {th }}-15^{\text {th }}$ of September 2013

The simulated hydrograph catches the three peaks of the hydrograph, with different phase and amplitude errors for each of them. The first peak has small phase and amplitude errors.

\section{CONSTANT LOSS Method for infiltrations}

Several simulations were performed using the radar precipitations, gradually decreasing the constant infiltration throughout the rain.

We reached the conclusion that the value $18.7 \mathrm{~mm}$ for the parameter Constant Loss led to a peak discharge of $117.99 \mathrm{~m}^{3} / \mathrm{s}$ with a $0.01 \%$ decrease and a 2.5 hours delay compared to the maximum recorded discharge.

The analysis of the results showed that the maximum peak simulated is an inverse ratio of the Constant Loss parameter. The excess rainfall that produces the surface runoff is diminished by the constant infiltration throughout the storm. The increase of the Constant Loss parameter doesn't influence the moment of occurrence of the hydrograph peak.

PROPORTIONAL LOSS Method for infiltrations

Several simulations were performed gradually increasing the value for the parameter Runoff coefficient, starting with the value 0.12 , till we established a 
value for the parameter which led to a discharge hydrograph similar to the measured hydrograph, by phase and amplitude.

We reached the conclusion that the value $\mathbf{0 . 2 8} \mathbf{~} \mathbf{m m}$ for the parameter Runoff coefficient led to a peak discharge of $118.68 \mathrm{~m}^{3} / \mathrm{s}$ with a $0.57 \%$ increase and a 2.5 hours delay compared to the maximum recorded discharge.

The analysis of the results showed that the maximum peak simulated is an inverse ratio of the Runoff Coefficient parameter that diminishes the excess rainfall and therefor the surface runoff. The increase or decrease of the Runoff Coefficient parameter doesn't influence the moment of occurrence of the hydrograph peak.

SCS GENERALISED Method for infiltrations

Several simulations were performed using different values for the Initial abstraction depth parameter, till we established a value for the parameter, which led to a discharge hydrograph similar to the measured hydrograph, by phase and amplitude.

We reached the conclusion that the value $95 \mathbf{m m}$ for the parameter Initial abstraction depth led to a peak discharge of $124.48 \mathrm{~m}^{3} / \mathrm{s}$ with a $5.49 \%$ increase and a 26.5 hours delay compared to the maximum recorded discharge.

The analysis of the results showed that the simulated hydrograph has four peaks and the first peak has a diminished value, compared to the maximum recorded discharge. The second simulated peak is the maximum peak and has an increased value, compared to the maximum recorded discharge. The volume of the simulated flood is $11796236 \mathrm{~m}^{3}$, compared to the volume of the recorded flood of $3138318 \mathrm{~m}^{3}$, with a $276 \%$ increase.

The analysis of the results showed that the hydrological modeling that used radar precipitations led to a discharge hydrograph with smaller phase and amplitude errors, compared to hydrograph simulated with the precipitations recorded at AHSS Cudalbi.

The radar precipitations describe the storm with a high accuracy, so the simulations performed using this input data led to a discharge hydrograph with a sequence of peaks which is close to the real discharge hydrograph. The delay between the moment of occurrence of the maximum simulated peak is of 2.5 hours, when using the radar precipitations for the simulations.

The following results were obtained using precipitations recorded by AHSS Cudalbi (table 1) and radar precipitations (table 2): 
Tab. 1. Simulation results with the precipitations recorded by AHSS Cudalbi as input data

\begin{tabular}{|c|c|c|c|c|}
\hline $\begin{array}{c}\text { Infiltration } \\
\text { losses - Method }\end{array}$ & Parameters & $\begin{array}{l}\text { Maximum } \\
\text { simulated } \\
\text { discharge }\end{array}$ & $\begin{array}{r}\text { Errors cor } \\
\text { maximu } \\
\text { recorded at } \\
\text { amplitude } \\
\end{array}$ & $\begin{array}{l}\text { mpared to the } \\
\text { m discharge } \\
\text { AHSS Cudalb } \\
\text { phase } \\
\end{array}$ \\
\hline SCS & $\begin{array}{c}C N=74 \\
\text { Initial } A M C \text { (Antecedent } \\
\text { Moisture Coefficient) }=1 \\
\text { Area adjustment } \\
\text { factor }=0.71\end{array}$ & $120.10 \mathrm{~m}^{3} / \mathrm{s}$ & $+1.8 \%$ & +7 hours \\
\hline Constant Loss & $\begin{array}{c}\text { Initial Loss }=18.8 \mathrm{~mm} \\
\text { Constant Loss }=26 \mathrm{~mm} / \text { hour } \\
\text { Area adjustment } \\
\text { factor }=0.71\end{array}$ & $118.85 \mathrm{~m}^{3} / \mathrm{s}$ & $+0.7 \%$ & +6 hours \\
\hline $\begin{array}{l}\text { Proportional } \\
\text { Loss }\end{array}$ & $\begin{array}{c}\text { Runoff coefficient }=0.27 \\
\text { Area adjustment } \\
\text { factor }=0.71\end{array}$ & $117.71 \mathrm{~m}^{3} / \mathrm{s}$ & $-0.2 \%$ & +6 hours \\
\hline $\begin{array}{c}\text { SCS } \\
\text { generalized }\end{array}$ & $\begin{array}{c}C N=74 \\
\text { Initial abstraction depth=73 } \\
\mathrm{mm} \\
\text { Area adjustment } \\
\text { factor }=0.71\end{array}$ & $118.09 \mathrm{~m}^{3} / \mathrm{s}$ & $+0.08 \%$ & +7 hours \\
\hline
\end{tabular}

Tab. 2. Simulation results with the radar precipitations as input data

\begin{tabular}{|c|c|c|c|c|}
\hline \multirow{2}{*}{$\begin{array}{l}\text { Infiltration } \\
\text { losses - } \\
\text { Method }\end{array}$} & \multirow[t]{2}{*}{ Parameters } & \multirow{2}{*}{$\begin{array}{l}\text { Maximum } \\
\text { simulated } \\
\text { discharge }\end{array}$} & \multicolumn{2}{|c|}{$\begin{array}{c}\text { Errors compared to the } \\
\text { naximum discharge recorded at } \\
\text { AHSS Cudalbi }\end{array}$} \\
\hline & & & amplitude & phase \\
\hline SCS & $\begin{array}{c}C N=74 \\
\text { Initial } A M C(\text { Antecedent } \\
\text { Moisture Coefficient })=1 \\
\text { Area adjustment factor }=1 \\
\text { Initial Loss }=18.8 \mathrm{~mm}\end{array}$ & $120.72 \mathrm{~m}^{3} / \mathrm{s}$ & $+2.3 \%$ & +3 hours \\
\hline $\begin{array}{l}\text { Constant } \\
\text { Loss }\end{array}$ & $\begin{array}{c}\text { Constant Loss }=18.7 \\
\mathrm{~mm} / \text { hour } \\
\text { Area adjustment factor }=1\end{array}$ & $117.99 \mathrm{~m}^{3} / \mathrm{s}$ & $-0.01 \%$ & +2.5 hours \\
\hline $\begin{array}{l}\text { Proportional } \\
\text { Loss }\end{array}$ & $\begin{array}{l}\text { Runoff coefficient }=0.28 \\
\text { Area adjustment factor }=1 \\
\qquad N=74\end{array}$ & $117.71 \mathrm{~m}^{3} / \mathrm{s}$ & $-0.57 \%$ & +2.5 hours \\
\hline $\begin{array}{c}\text { SCS } \\
\text { generalized }\end{array}$ & $\begin{array}{c}\text { Initial abstraction } \\
\text { depth }=95 \mathrm{~mm} \\
\text { Area adjustment factor }=1\end{array}$ & 124.48 & $+5.49 \%$ & +26.5 hours \\
\hline
\end{tabular}




\section{Conclusions}

It seems that among the four methods for determining the infiltration losses, the Proportional Loss method leads to a discharge hydrograph with a sequence of peaks which is close to the real discharge hydrograph, and has smaller phase and amplitude errors (figure 6).

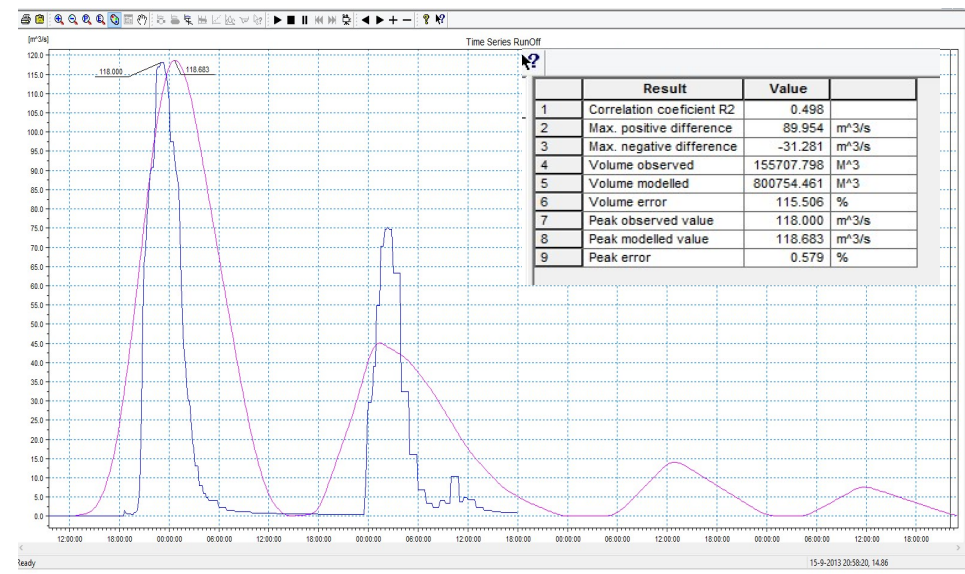

Fig. 6. Simulated and recorded discharge hydrograph (__ simulated, recorded)

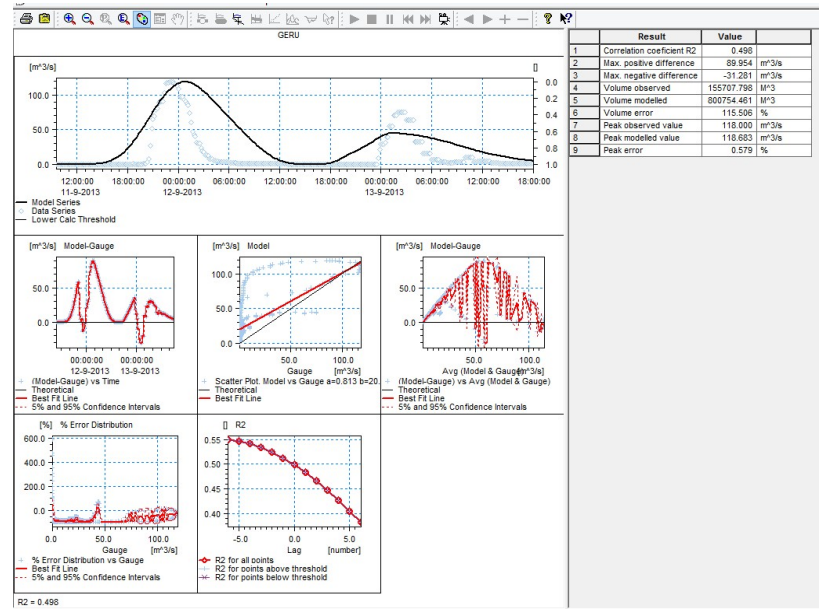

Fig. 7. Statistical analysis for the simulated results

The correlation coefficient between the simulated hydrograph and the recorded hydrograph at AHSS Cudalbi is 0.498 (figure 7). 
For similar catchments where automated station are installed, the model can be adapted using the same concept, to forecast discharge hydrographs, based on estimated radar precipitations.

\section{References}

Administraţia Bazinală Prut - Bârlad, (2014), Raport anual de sinteză privind activitatea de urmărirea comportării construcțiilor din patrimoniul Administrației Bazinale de Apă Prut - Bârlad în anul 2013

Apostol, A., (2011), Teză de doctorat - Modelarea scurgerii lichide și solide în bazine hidrografice cu activități agrosilvice, aplicații în prognoza hidrologică, Universitatea Tehnică de Construcții Bucureşti - Facultatea de Hidrotehnică

Balan, I. Pricop, C., Crenganiș, L., (2015), Flood analysis using hydrological modeling. Case study - the flood in the upper catchment of river Geru, Galaţi county, Romania, simpozionul Present Environment and Sustainable Development, Universitatea Alexandru Ioan Cuza - Facultatea de Geografie și Geologie

Bîrsan, M.V., (2010), Teză de doctorat - Modelarea proceselor fizice de tip precipitațiescurgere pentru prognoza în timp real a viiturilor, Universitatea din Bucureşti Facultatea de Fizica - Școala Doctorala

Crăciun, I., Giurma, C.-R., (2014), Hidrologie specială - Aplicații, Ed. Performantica, Iaşi

Domnița, M., (2012), Teză de doctorat - Runoff modeling using GIS. Application in torrential basins in the Apuseni Mountains, Universitatea Babeș Bolyai Cluja Napoca - Facultatea de Geografie

Hjelmfelt, A.T. Jr, Kramer K.A., Burwell R.E., (1982) Curve number as random variables, Proc. Int. Symp on Rainfall - Runoff Modeling (Ed. V.P. Singh), Water Resources Publication, Littleton, Colo. 365-373

Kirkby, M., (1971) Hillslope process - response models based on the continuity equation. In Slopes form and processes Instit. British Geography Specifications Pub. No. 3: 15 30

Mihsra, S.K., Singh V.P. (2003) Comparison of Existing and Modified SCS-CN Models, Proc. Int. Conference on Water and Envirnonment (WE - 2003) Bhopal, India, Colo. 365-373

McCuen, R.H., 1982, A Guide to Hydrologic Analysis Using SCS Methods Prentice Hall, Inc. Englewood Cliffs, New Jersey

Natural Resources Conservation Services USDA, (1986), National Engineering Handbook-Part 630 Hydrology, chapter 7-12

Natural Resources Conservation Services USDA, (1986), Urban Hydrology for Small Watersheds-Technical Release 55

Snyder, F.F., Trans. Am. Geophys. Union, 1938, No.19, Synthetic Unit Hydrographs pp. $447-454$

*** (2003), MIKE 11 - A modelling system for rivers and channels - User guide - DHI Agern Alle 5, DK-2970 Horsholm, Denmark 
***(2003), MIKE $11-A$ modelling system for rivers and channels - Short introduction tutorial - DHI- Agern Alle 5, DK-2970 Horsholm, Denmark

***(2006), MIKE 11 Users Manual - DHI water and environment, DK-2970 Horsholm, Denmark DHI

***(2011), MIKE 11 Reference Manual - DHI water and environment, DK-2970 Horsholm, Denmark DHI

*** (1985) United States Department of Agriculture (USDA), Soil Conservation Service, National Engineering Handbook (NEH), Section 4 - Hydrology, Washington D.C.

*** (1986) United States Department of Agriculture (USDA), National Engineering Handbook, Part 630 Hydrology, chapter 7-12

*** (1985) United States Department of Agriculture (USDA), Urban Hydrology for Small Watersheds, Technical Release 55 (TR-55), Natural Resources Conservation Service, Conservation Engineering Division 